\title{
Relations among Sap Flow, Soil Moisture, Weather, and Soybean Plant Parameters in High Water Demand and Final Growth Stages
}

\author{
Mukhammadzakhrab Ismanov, Paul Francis, Christopher Henry, Leonel Espinoza \\ Department of Crop, Soil and Environmental Sciences, University of Arkansas, Fayetteville, AR, USA \\ Email: mismanov@uaex.edu
}

How to cite this paper: Ismanov, M., Francis, P., Henry, C. and Espinoza, L. (2019) Relations among Sap Flow, Soil Moisture, Weather, and Soybean Plant Parameters in High Water Demand and Final Growth Stages. Agricultural Sciences, 10, 371-385.

https://doi.org/10.4236/as.2019.103030

Received: February 11, 2019

Accepted: March 22, 2019

Published: March 25, 2019

Copyright $\odot 2019$ by author(s) and Scientific Research Publishing Inc. This work is licensed under the Creative Commons Attribution International License (CC BY 4.0).

http://creativecommons.org/licenses/by/4.0/

cc) (i) Open Access

\begin{abstract}
The dynamics of sap flow in relation to plant morphology and weather conditions during reproductive growth of soybean (Glycine max. L. Merr.) influence decisions pertaining to efficient irrigation management and other inputs for high yields. Field studies began in 2017 at Marianna, Arkansas to measure moisture dynamics of soybeans during seed fill (R5 to R7) using heat balance stem flow gauges. Sap flow was highly correlated to solar radiation with maximum rates observed during beginning seed fill (R5). A solar radiation efficiency (SRE) value, calculated as hourly sap flow rate per Watt-hour of solar radiation $\left(\mathrm{g} / \mathrm{Wh}^{2}\right)$, is proposed. The SRE relates to crop water demand and hydraulic resistance of the soil-root-stem-leaf-pod-seed pathway. SRE values ranged from $0-1.2 \mathrm{~g} / \mathrm{Wh}^{2}$. Soil moisture, growth stage, time of day, and weather conditions influenced the SRE, with higher values observed in the morning, late afternoon, and during R5 growth. Peak sap flows of $39 \mathrm{~g} / \mathrm{h}$ at $\mathrm{R} 5,25 \mathrm{~g} / \mathrm{h}$ at R6, and $3 \mathrm{~g} / \mathrm{h}$ at R7 occurred. The ratio of measured sap flow to estimated crop evapotranspiration was 0.9 to 1.3 during R5 to R6.9 (maximum dry matter), but dropped to 0.2 at R7. Further research is needed to better understand late season reproductive moisture dynamics in soybeans.
\end{abstract}

\section{Keywords}

Sap Flow, Growth Stage, Evapotranspiration, Soil Moisture, Solar Radiation, Soil Water, Water Resistance, Plant Water Use

\section{Introduction}

Understanding soybean (Glycine max. L. Merr.) water dynamics in relation to the soil moisture content and weather conditions during late reproductive growth stages will improve water management and irrigation scheduling and irriga- 
tion-termination timing. Water demand of soybean plants varies with growth stage and weather conditions [1]. In every moment of the plant life cycle, nutrients in soil water are absorbed through the plant root system and transported to stems, leaves, and pods by osmosis hydraulic potentials created by xylem and phloem microcapillaries and leaf evapotranspiration. Soil water resistance and hydraulic conductance plant regulate sap flow. Some authors found that hydraulic conductance of the soybean plant was not flow dependent [2]. Investigations of sap flow characteristics in different soil water resistance, growth stages and weather conditions can improve irrigation management decisions.

In controlled environment studies, transpiration rates of soybean and maize (Zea mays, L.) declined rapidly at high soil matric potential and then dropped more slowly as the soil dried [3]. Although measured transpiration rate declined by nearly $30 \%$ following a reduction of soil matric potential to $-0.1 \mathrm{MPa}$, differences in leaf water potential and $\mathrm{CO}_{2}$ assimilation rate were small and less than the sensitivity of the measurement techniques used. Total system resistance to water flow increased as the soil dried. Whether or not these patterns occur in actual real field conditions is unclear.

Other researchers detail sap flow regulation by soil moisture, solar radiation, air temperatures, and vapor pressure deficits [4] [5]. Sap flow rates of soybeans and upland cotton (Gossypium hisutum, L.) were lower in humid conditions than arid conditions in both species [6]. Leaf temperature of the soybean cultivar changed almost in parallel with the air temperature during the daytime. On the other hand, the leaf temperatures of cotton were higher than the air temperatures until mid-noon. Under the arid condition, the leaf temperatures of cotton were higher than that of soybean and the air temperature. There was no significant difference in leaf temperature among the cotton and soybean cultivars under humid conditions. The flow rates of stem sap in the cotton cultivars under the arid condition were always higher than that in the soybean cultivar, and were largely affected by vapor pressure deficit (VPD). Under the humid condition, however, the flow rates of stem sap were lower in the cotton cultivars than in the soybean cultivars. Researchers show that in leaf energy balance, the rate of energy attributed to water evaporation is from $20 \%$ to $40 \%$ [7] [8].

Sap flow measuring methods include stomatal conductance [9], plant chambers [10], lysimeters [11], and field water balance [12]. The thermal method [13], installed using plant stem electric heaters and temperature sensors, is a relatively accurate and easy to use in field conditions. The objectives of this study were to investigate late season reproductive moisture dynamics of soybeans in relation to plant and environmental conditions using sap flow monitoring. The findings will lead to improved late season irrigation and pest management.

\section{Materials and Methods}

Soybeans ("Dyna-Gro 39RY43", maturity group rating 3.9, http://www.dynagroseed.com) were planted on 19 April 2017 at the Lon Mann 
Cotton Research Station, Marianna, Arkansas USA (34 $\left.{ }^{\circ} 43^{\prime} 58.08^{\prime \prime} \mathrm{N}, 90^{\circ} 45^{\prime} 58.46^{\prime \prime} \mathrm{W}\right)$. All cultivation and pest control practices were performed according to current recommendations of the University of Arkansas Extension Service. Soybean seeds were planted $0.96 \mathrm{~m}$ wide-row spacing and 271,700 seeds/ha. Final plant stand was determined by counting seedlings/61 $\mathrm{m}$ random row sections and averaged 269,230 plants/ha. Due to $470 \mathrm{~mm}$ of precipitation in the 2017 growing season ( $78 \%$ of more than average precipitation in the study area) and with 434 $\mathrm{mm}$ of potential evapotranspiration, the numbers of irrigation events were three times less than an average year. Potential evapotranspiration (ET) was recorded hourly using digital atmometers installed at the edges of the plots (etgage.com, Loveland Colorado). WaterMark ${ }^{\mathrm{rm}}$ soil moisture sensors installed at 15, 30, 45, and $76 \mathrm{~cm}$ depths and connected to $900 \mathrm{M}$ Watermark monitor data logger (Irrometer, Riverside, California, USA) recorded soil moisture (Cbars) every hour. Once a week during vegetative growth, gravimetric soil moisture content $(\mathrm{g} / \mathrm{g})$ and soil bulk density $\left(\mathrm{g} / \mathrm{cm}^{3}\right)$ were measured to a depth of $91 \mathrm{~cm}$ in $15 \mathrm{~cm}$ intervals. The amount of soil water $(\mathrm{cm})$ in the upper $91 \mathrm{~cm}$ of soil was determined by:

$$
W_{n}=\sum_{i=1}^{n} S_{m i} * \sigma_{i} * H_{i} / 100
$$

where, $W_{n}$-Amount of water $(\mathrm{cm})$ at from 1 to $\mathrm{n}$ layers of soil;

$S_{m i}$-Gravimetric soil moisture in different depth intervals (\%);

$H_{i}$ - Height of soil depth intervals $(\mathrm{cm})$;

$\sigma_{i}$-Soil bulk density $\left(\mathrm{g} / \mathrm{cm}^{3}\right)$.

Soil temperature $\left({ }^{\circ} \mathrm{C}\right)$ was measured at 3 and $15 \mathrm{~cm}$ depths by iBWetL and temperature data loggers and WaterMark temperature sensors. Plant leaf, pod, and stem temperature was measured by infrared thermometer. Plant height, width, number of nodes, leaves, and stem diameter was measured weekly. Plant leaf and pod areas and plant moisture content was measured from random plants at R5, R6, R6.5, and R7 growth stages [14]. Weather parameters were recorded with Watch Dog 2900 ET Weather Station (Spectrum Technologies, Aurora, IL, USA) installed adjacent to the field.

SGB-9 WS sap flow sensors (Dynamax Inc., Fresno, CA, USA) were installed on random plants using $9 \mathrm{~mm}$ collars when stem diameter growth allowed. The Flow32-1K system is supplied with a data logger, multiplexer for up to 8 Dynagages, and AVRD for supplying sensor heater voltage assembled in a weatherproof enclosure. The datalogger is powered using a 12 volt marine battery and solar panel. Sensors are installed approximately $15-20 \mathrm{~cm}$ above the soil surface and wrapped with several isolators to keep heat energy in the plant stem. Each sensor is equipped with heater and temperature sensors that recorded upcoming and outgoing sap stream temperatures. Sap flow was calculated and recorded in 10 minute time intervals. Sap flow was expressed as the average $\mathrm{g}$ of water per plant measured and adjusted to $\mathrm{cm}$ of water transpired using the average plant density of the field (plants/ha) determined from a nearby row of $10 \mathrm{~m}$ length, where \# random plants were sampled. 
To determine the plant sap flow influence on leaf temperature, random plants of soybeans and cotton (Gossypium hirsutum, L.) were tied to wooden stakes installed next to the plants. Main stems of half the staked plants were carefully excised and leaf and air temperature monitored until sunset. The influence of sap flow on leaf temperatures was investigated by comparing cut versus un-cut plants.

Another experiment was performed with mature soybean plants to determine the amount of capillary water absorbed in the upper foliage in wet soil. Twelve, mature soybean plants with attached roots were carefully extracted from the soil and dried 24 hours in a forced air drier. Seeds of all plants were removed from the pods and the petioles, pods, seeds, and branches from six random plants removed and stored for 48 hours at $25^{\circ} \mathrm{C}$ and $50 \%$ + relative humidity to standardize tissue integrity between plants. The plants were then replanted in the field at the same depth and position prior to initial excavation. After replanting, half the plants were hand watered for $48 \mathrm{hrs}$. Plants were removed from the soil on the third day and whole plant, roots, and stem weighed in identical temperature and humidity. The weather was sunny and no rain received during the three days after replanting. Collected variable data was analyzed using scattered diagram method, regression analyses, calculating coefficient of determination $\left(\mathrm{R}^{2}\right)$ and p-value to evaluate the functional relations using SAS (SAS Inst., Cary, NC) and EXCEL data analyses ToolPak.

\section{Results and Discussions}

Sap flow, irrigation, rainfall, and evapotranspiration varied with growth stage and generally declined from R5 to R7 growth (Figure 1). Maximum sap flow occurred in the middle of July (growth stage R5). Sap flow slowly decreased in the end of July until mid-August (R6 - R6.5) and then decreased rapidly until the end of August (R7). In September, sap flow was relatively steady with seven times less rate than maximum sap flow rates in July. The data revealed minute sap flow occurring in R8 growth stage, when soybean stems become dry and brown. The moisture use during R8 was most likely due to capillary forces since photosynthesis and dry matter gains of the plant had ceased.

Sap flow had a high correlation with ET (Figure 2). Sap flow peaked at 0.84 $\mathrm{cm}$ when ET demand was approximately $0.69 \mathrm{~cm}$. Sap flow decreased approximately $10 \%-15 \%$ when ET rates increased from $0.69 \mathrm{~cm}$ to $0.79 \mathrm{~cm}$. Plant water use in the middle of July, as indicated by sap flow measurements, was higher than potential ET. Therefore, the data indicates that in high water use growth stages of soybeans, the crop coefficient, Kc, should be around 1.3. From the middle of July to the middle of August, sap flow and potential ET rates were similar, indicating a Kc around 1. The Kc dropped to around 0.25 in late August.

Sap flow increased after every irrigation and rainfall event, slowly reaching a maximum rate and then sharply decreasing. The pattern of slow increase of sap flow followed by quick declines after rain or irrigation continued until R7 growth. Solar radiation, ET, air temperatures, humidity, and wind speed also influenced sap flow rates during these cycles. Comparing sap flow and soil-water tension 


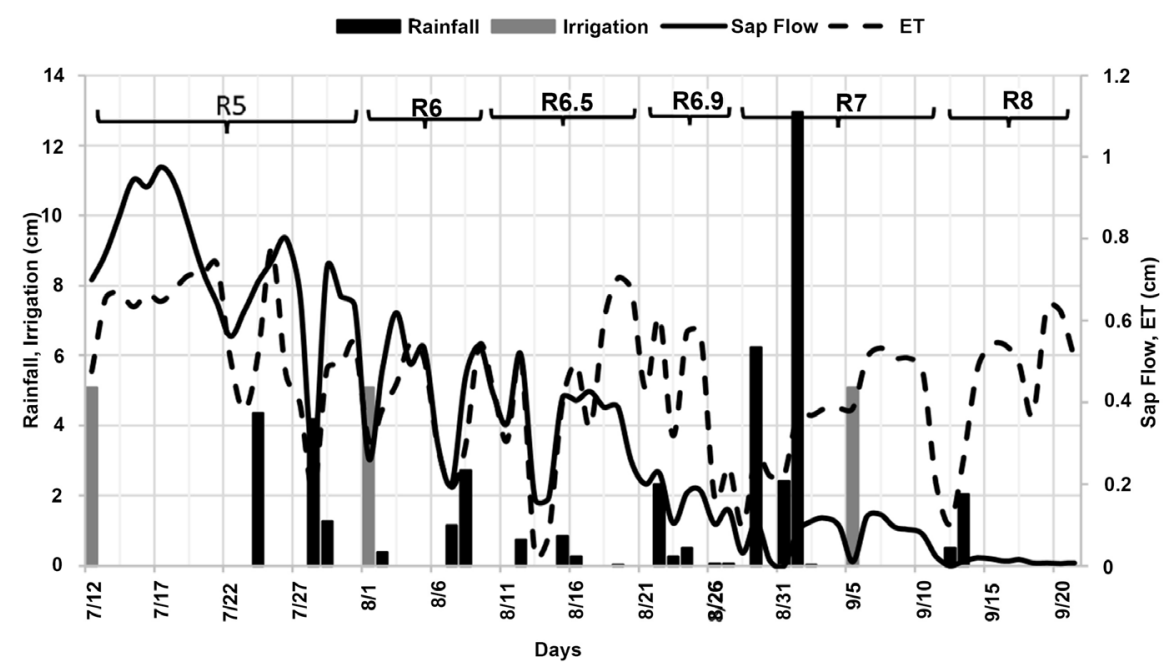

Figure 1. Daily average sap flow, rainfall, irrigation, and evapotranspiration in final growth stages of soybean, 2017, Lon Mann Cotton Research Station, Marianna AR.

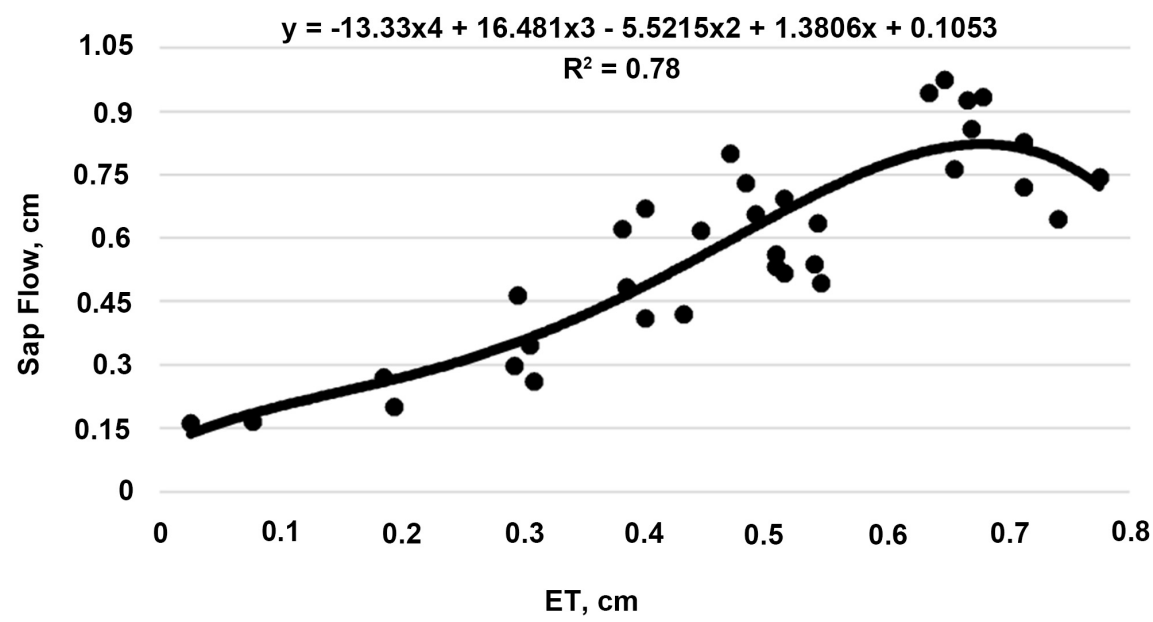

Figure 2. Relationship between measured sap flow and apparent evapotranspiration (p-value < 0.01), 2017, Lon Mann Cotton Research Station, Marianna AR.

(Cbars) at $15 \mathrm{~cm}, 30 \mathrm{~cm}, 46 \mathrm{~cm}$, and $61 \mathrm{~cm}$ depths (Figure 3) reveals that increases in soil moisture (decreasing soil-water tension) increased sap flow (shown in circles in Figure 3).

To determine the relationship between soil water and sap flow, we looked at the correlation between sap flow and soil water in $0-76 \mathrm{~cm}$ depths in time intervals between irrigations and rainfalls from 17-23 July 2017 to 8-14 Aug. 2017 (Figure 4). Significant $\mathrm{R}^{2}$ coefficients of 0.91 during 9-14 Aug. 2017 (R6 growth) and 0.74 during 17-23 July 2017 (R5 growth) occurred.

Sap flow has a good correlation with the plant development. Our measurements show that sap flow rates can influence plant biomass accumulation. Daily plant ET was less than sap flow during rapid seed fill gains. Therefore, some amount of water and nutrients in the daily sap flow contributed to increases in plant biomass. Preliminary measurements show that daily contribution of sap 


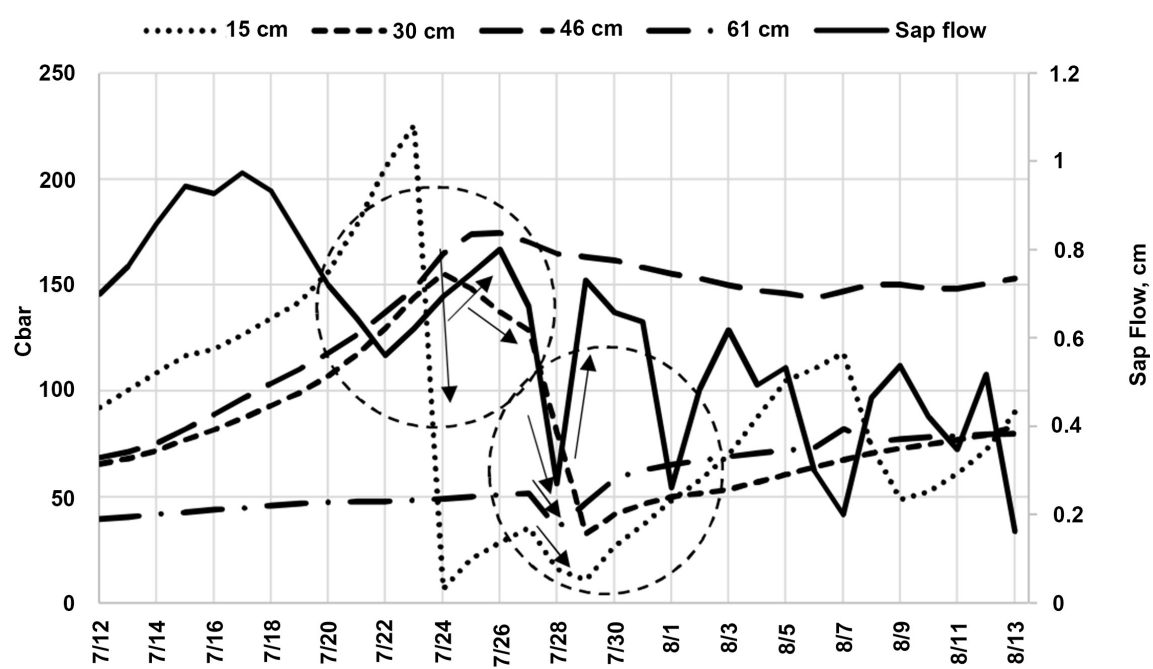

Figure 3. Soil moisture at different depths and plant sap flow between July 12, 2017 and August 13, 2017, Lon Mann Cotton Research Station, Marianna AR.

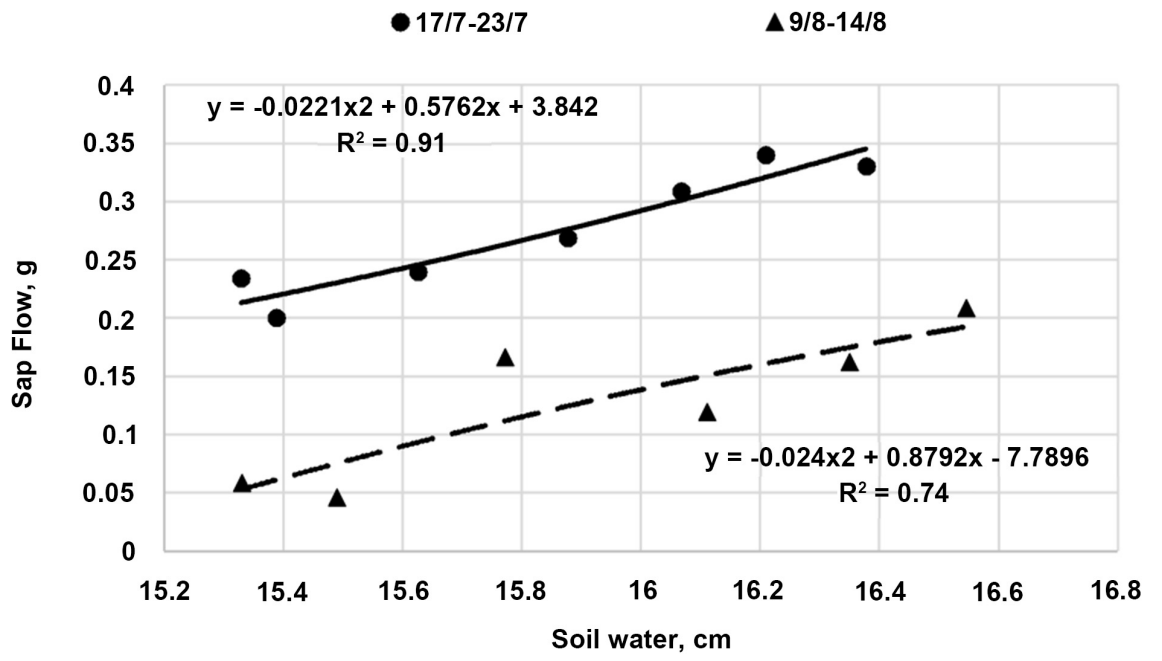

Figure 4. Relationship of sap flow and estimated soil water from surface to $76 \mathrm{~cm}$ depth during 9-14 August (p-value < 0.01), and 17-23 August (p-value < 0.05) 2017, Lon Mann Cotton Research Station, Marianna AR.

flow, $Q_{b}$, to the plant biomass is approximately $0.5 \%-0.8 \%$ of sap flow rate in R5 growth stage and $0.8 \%-1.2 \%$ in R6 growth stage. Higher contribution rate of sap flow to plant biomass during R6 may be due to rapid seed weight gain and remobilization processes [15].

Sap flow is highly correlated with solar radiation, the main source of energy needed for photosynthesis, water evaporation, sap flow and nutrient uptake and transport. The solar energy received by a single plant, $W_{i}$ could be calculated by:

$$
W_{i}=\frac{W_{0}}{n} k(1-\alpha),
$$

where, $W_{0}$-Solar radiation per meter square measured by sensors, $\mathrm{W} / \mathrm{m}^{2}$; 
$n$-Number of plants $/ \mathrm{m}^{2}$;

$k$-Coefficient depending of the leaf area index (LAI) or percent of canopy cover (when LAI > 1, $k=1$ );

$\alpha$-Coefficient depending on transmitted and reflected part of the radiation.

For example, at $11: 00$ on 13 July 2017 the gravimetric soil moisture was $12 \%$ at 0 - $15 \mathrm{~cm}$ depths, temperature $29^{\circ} \mathrm{C}$, air temperature $30^{\circ} \mathrm{C}$, relative humidity $69.7 \%, W_{0}=799 \mathrm{~W} / \mathrm{m}^{2}, \mathrm{n}=26.9 \mathrm{~m}^{-2}$, and $k=1$. According to Brown and Gillespie [16], a single layer of leaves will generally absorb $80 \%$ of incoming visible radiation, whilst reflecting $10 \%$ and transmitting $10 \%$. Approximately $20 \%$ of infrared radiation is absorbed with $50 \%$ being reflected and 30\% is transmitted [13] [14]. Considering this, the hourly solar energy received by the single plant in this time is $W_{i}=23.7 \mathrm{~W} / \mathrm{m}^{2}$. The hourly work, fulfilled of this energy equals 85,434 Joules. The amount of the evaporated water $Q_{e v}$ by the particular plant is less than sap flow and equals

$$
Q_{e v}=Q_{s f}-Q_{b}
$$

where, $Q_{s f}$-daily amount of sap flow;

$Q_{b}$-daily contributed amount of sap flow to the biomass of the plant.

The energy needed to heat and vapor $30.9 \mathrm{~g}$ of water $\left(Q_{e v}\right)$ for this particular plant in given field conditions is 53,420 Joules. Accordingly, $62.5 \%$ of total solar energy received by the plant is required for water evaporation. The energy used for water evaporation is $54.4 \%$ of all solar radiation received by the plant on this day. At 11:00 on 22 July 2017, the soil moisture was $7 \%$ at $0-15 \mathrm{~cm}$ depths and calculations show that $22.7 \%$ of solar energy received by the plant utilized for evaporation. Daily average energy spent for evaporation from the total solar radiation received by the plant on that day was $15.4 \%$. To evaluate the process of water evaporation or sap flow uptake by the plants, we recommend a solar radiation efficiency (SRE) value defined as the ratio between hourly solar energy received by the plant and amount of sap flow:

$$
S R E=Q_{e v} / W_{i} .
$$

where $S R E$ is the solar radiation efficiency expressing the amount of hourly sap flow with 1 Watt of solar radiation. The SRE at 11:00 was $0.89 \mathrm{~g} / \mathrm{Wh}^{2}$ on 13 June 2017 and $0.32 \mathrm{~g} / \mathrm{Wh}^{2}$ on 22 July 2017. Due to the short amount of time between these two days, the plant hydraulic resistance, potential energy demand, leaf area of the plant, and received solar energy are comparable. There were, however, differences in the soil moisture. Decreasing the soil moisture from 12 to $7 \%$ at the top $0-15 \mathrm{~cm}$ soil layers decreased the SRE coefficient due to increases in the total work to move water from the deeper soils to roots, stems, leaves, and finally to evaporation (Figure 5 and Figure 6). As a result, the sap flow is 3.4 times less for drier soils in relatively the same weather conditions and plant parameters.

Sap flow begins at 8:00, while solar radiation to the plant began between 6:00 and 7:00. The delay of sap flow was due to the existing dew and excess moisture on the surface of the leaves in the early morning hours. Comparison of sap 


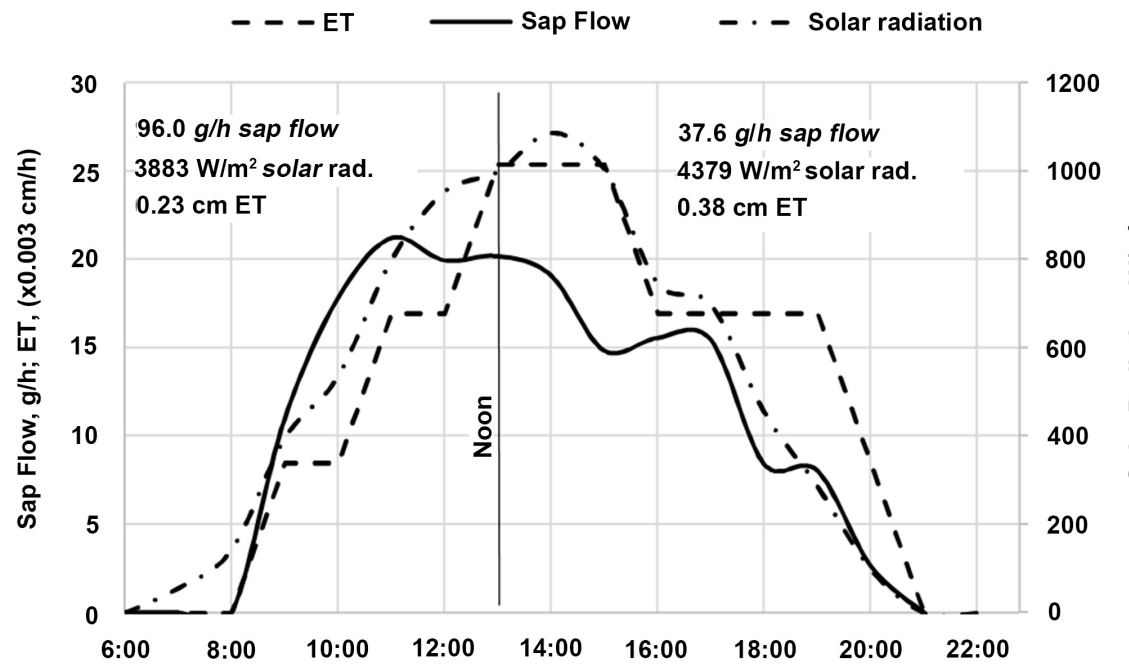

Figure 5. Hourly sap flow of soybean, solar radiation, and evapotranspiration when relative soil moisture is $13 \%, 20 \%$, and $21 \%$ at $0-15,15-30,30-45 \mathrm{~cm}$ depths respectively on 13 July 2017, Lon Mann Cotton Research Station, Marianna AR.

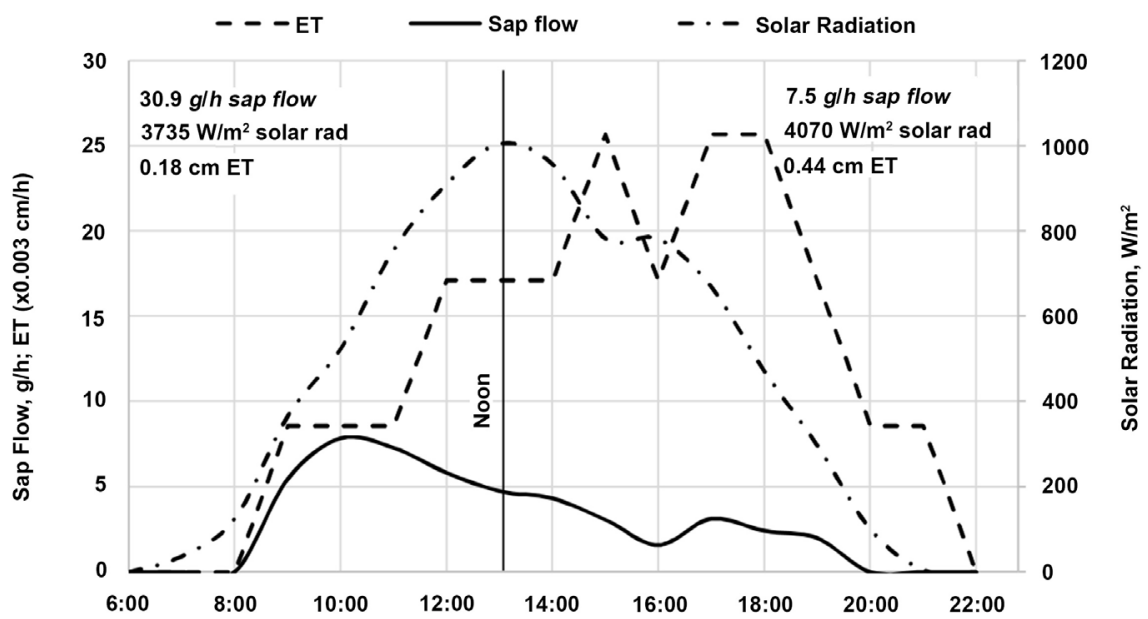

Figure 6. Hourly sap flow of soybean, solar radiation, and evapotranspiration when relative soil moisture is $7 \%, 18 \%$, and $20 \%$ at $0-15,15-30,30-45 \mathrm{~cm}$ depths respectively on 22 July 2017, Lon Mann Cotton Research Station, Marianna AR.

flow and hourly evapotranspiration shows that sap flow is higher in the morning hours than in the afternoon hours, despite that ET and solar radiation are higher in the afternoon hours than in the morning hours. This is most likely due to the leaf stomata regulation's effect [17] and increasing water tension in the soil. When water tension is high (soil moisture is less) the sap flow delays are longer with less flow.

SRE is relatively higher in the morning hours because there is sufficient water in the plant leaf cells and water resistance is low in this time of the day (Figure 7). As water evaporates from the leaves, moisture demand and sap flow increases and an apparent transpiration resistance occurs resulting in lower SRE values in the afternoon hours. At the end of the day when solar radiation decreases, 


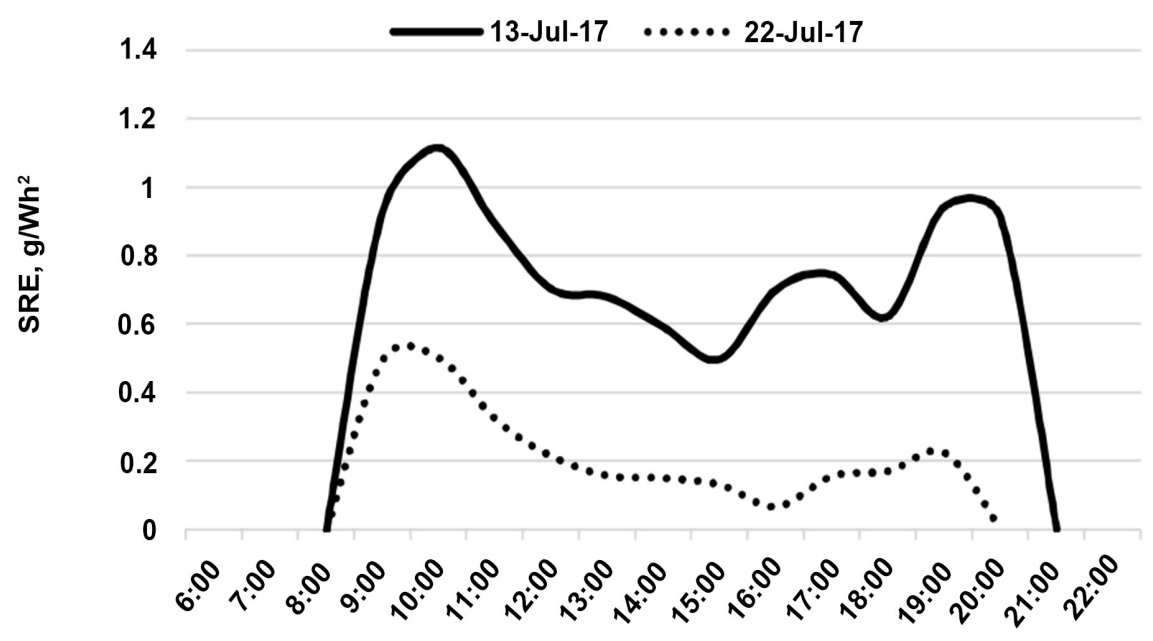

Figure 7. Solar Radiation Efficiency (SRE) for soybeans at 13 July 2017 and 22 July 2017, Lon Mann Cotton Research Station, Marianna, AR.

evapotranspiration and water resistance decrease and consequently SRE increases again. The same effect occurs when soil moisture is low: SRE is higher when the soil moisture is $13 \%, 20 \%$, and $21 \%$ at $0-15,15-30,30-45 \mathrm{~cm}$ depths respectively than when the soil moisture is $7 \%, 18 \%$, and $20 \%$ at $0-15,15-30,30$ - $45 \mathrm{~cm}$ depths respectively, even though leaf coverage and solar radiation were almost the same for the two days. The SRE is negatively proportional to the soil water resistance.

Measurements of soybean leaf surface temperature, $T_{1}$, and air temperature, $T_{\text {air }}$ at various growth stages were recorded. The difference between ambient air temperature and soybean leaf $(\Delta T)$ can be expressed as:

$$
\Delta T=T_{\text {air }}-T_{l},
$$

The $\Delta T$ can vary with many factors, including ET, solar radiation, air humidity and temperature, soil moisture, wind speed, and time of day. However, the main factor influencing $\Delta T$ is soybean growth stage. The average $\Delta T$ is around $2.7^{\circ} \mathrm{C}$ in high water use R5 growth and decreases to less than 0 at R7 and R8.

Results of the leaf surface temperature, air temperature, and hourly sap flow measurements for selected days in the final growth stages are depicted in Figures 8-10. Sap flow and $\Delta T$ are usually different during water demand in growth stage R5 except in the middle of the day, when they are relatively close to each other (Figure 8). The differences between air and leaf surface temperatures most likely occur due to high transpiration rates, as inferred by the high sap flows observed in R5 growth. Sap flow decreases almost twice in R6 growth relative to R5 growth and the difference between air and leaf temperatures decrease similarly, especially in the morning hours of the day (Figure 9). In R7 and R8 growth stage, when leaves are yellow or brown and plants are nearing maturity, leaf temperatures are similar to air temperatures, especially in afternoon hours (Figure 10). 


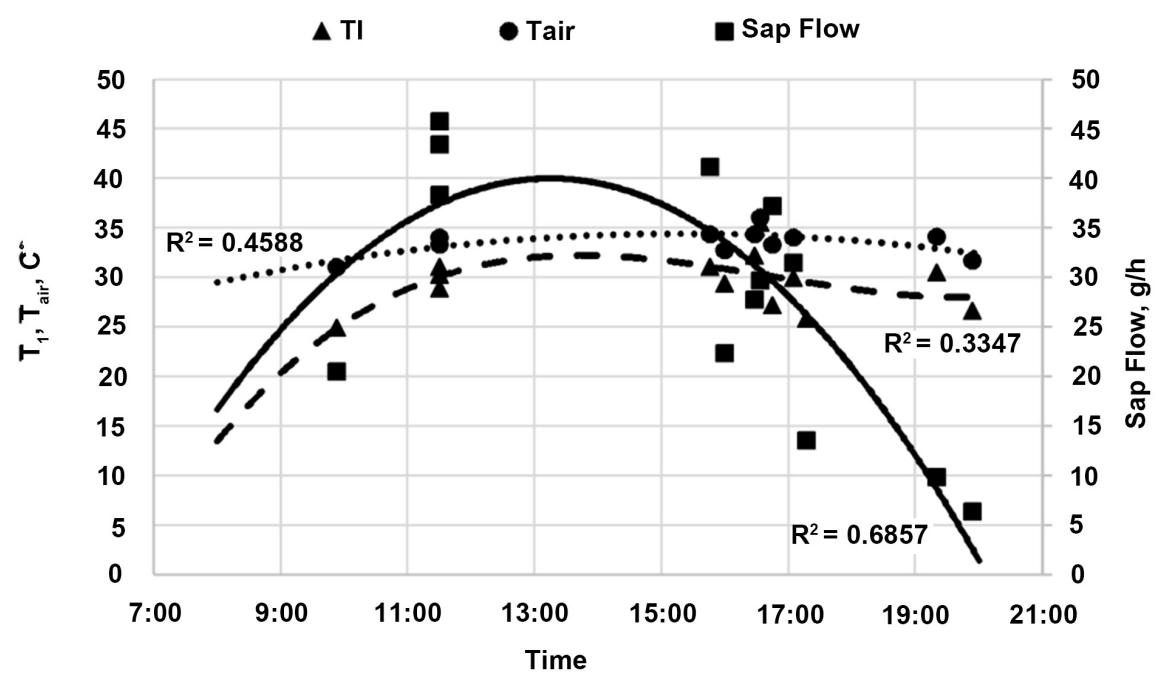

Figure 8. Relationship between leaf surface temperature, ambient air temperature, and sap flow at R5 growth stage, 13/7-30/7, 2017, Lon Mann Cotton Research Station, Marianna, $\mathrm{AR}$.

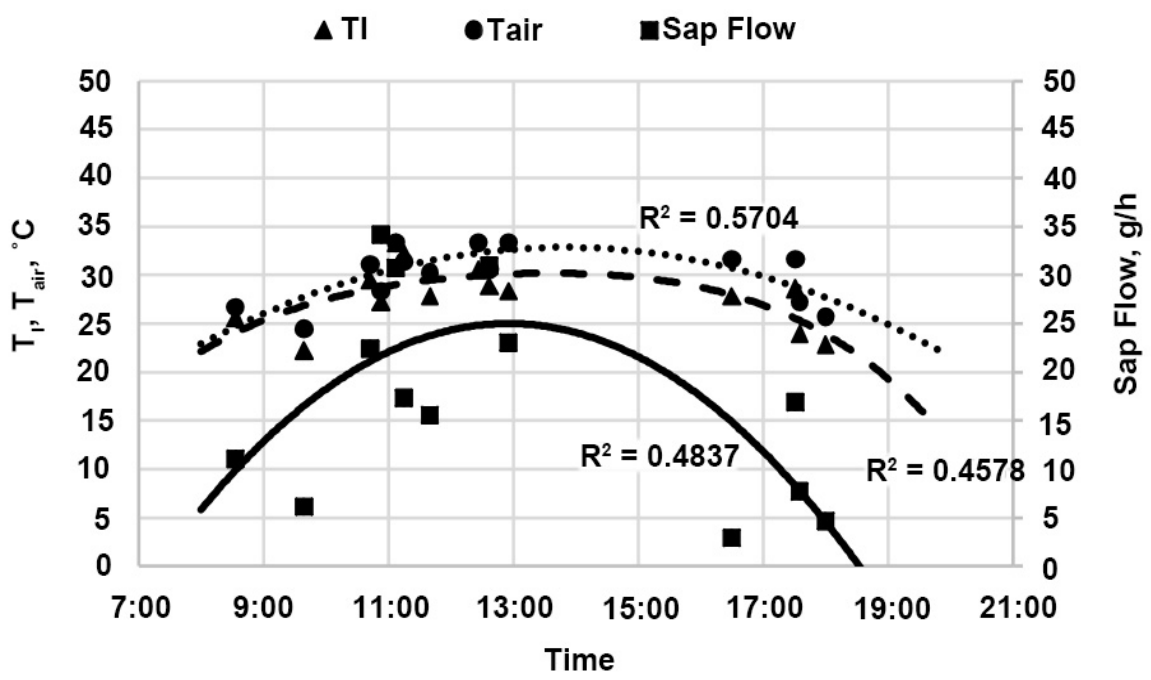

Figure 9. Relationship between leaf surface temperature, ambient air temperature, and sap flow at R6 growth stage, 1/8-25/8, 2017, Lon Mann Cotton Research Station, Marianna, AR.

To evaluate the sap flow impact on $\Delta T$, sap flow data was plotted in ascending order and compared to the average $\Delta T$ at four sap flow levels (Figure 11). Average $\Delta T$ is strongly correlated $(\mathrm{R}=0.96, \mathrm{p}<0.05)$ with sap flow and could be predicted by:

$$
\Delta T=1.6027 \ln \left(Q_{s f}\right)-1.3103
$$

Here, $Q_{s f}$ is the amount of sap flow in grams per hour.

Leaf surface temperatures of cut and uncut soybean plants near the same location in a field were different at R6 growth stage (Figure 12). Leaf temperatures of both cut and uncut plants are the same and about $3^{\circ} \mathrm{C}$ less than air temperature 


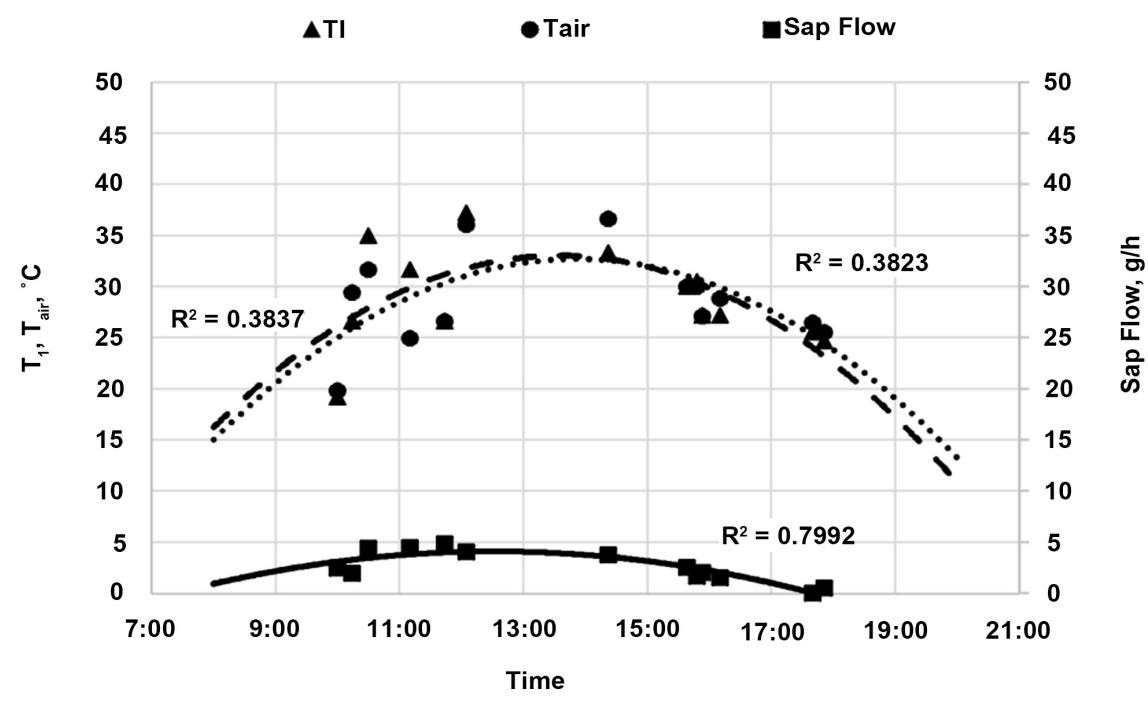

Figure 10. Relationship between leaf surface temperature, ambient air temperature, and sap flow at R7-8 growth stage, 26/8-18/9, 2017, Lon Mann Cotton Research Station, Marianna, AR.

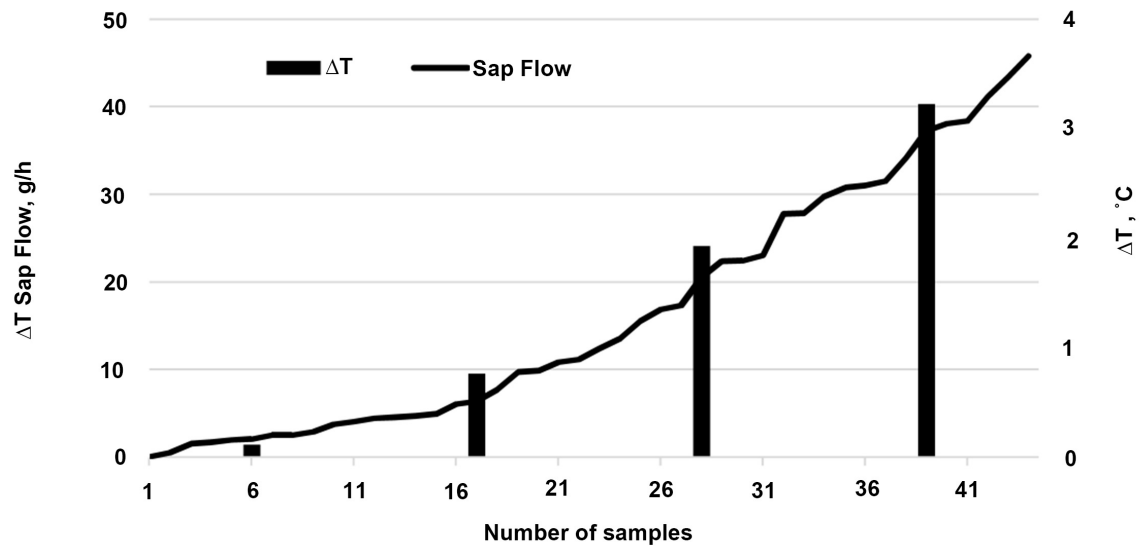

Figure 11. Sap flow and average temperature differences between air and leaf surface at 4 sap flow rates, 2017, Lon Mann Cotton Research Station, Marianna, AR.

and $9^{\circ} \mathrm{C}$ less than the soil surface around the plant. However, surface leaf temperature of the cut plants began to rise soon after cutting and was equal to air temperatures just after 13 minutes. The leaf surface temperature of uncut plants increased only about $0.6^{\circ} \mathrm{C}$ under the heat of $723 \mathrm{~W} / \mathrm{m}^{2}$ solar radiation in the same duration. Relative air humidity was $35 \%$ in this time. The leaf surface temperature of the cut plant reached its maximum $36^{\circ} \mathrm{C}$ about an hour after excise (around 16:00). Temperature of the cut plant leaves decreased from this point as the solar radiation dropped to $591 \mathrm{~W} / \mathrm{m}^{2}$. As solar radiation decreased until 408 $\mathrm{W} / \mathrm{m}^{2}$ at $17: 00$, the leaf surface temperature of cut plants decreased until the ground surface temperature was $31^{\circ} \mathrm{C}$. Leaf temperature of uncut plants during this hour was $25^{\circ} \mathrm{C}$, still lower than air temperatures, which were $29^{\circ} \mathrm{C}$. This experiment illustrates the role of soil moisture related to sap flow in leaf temperature dynamics. Decreasing sap flow or complete cessation of sap flow in the 


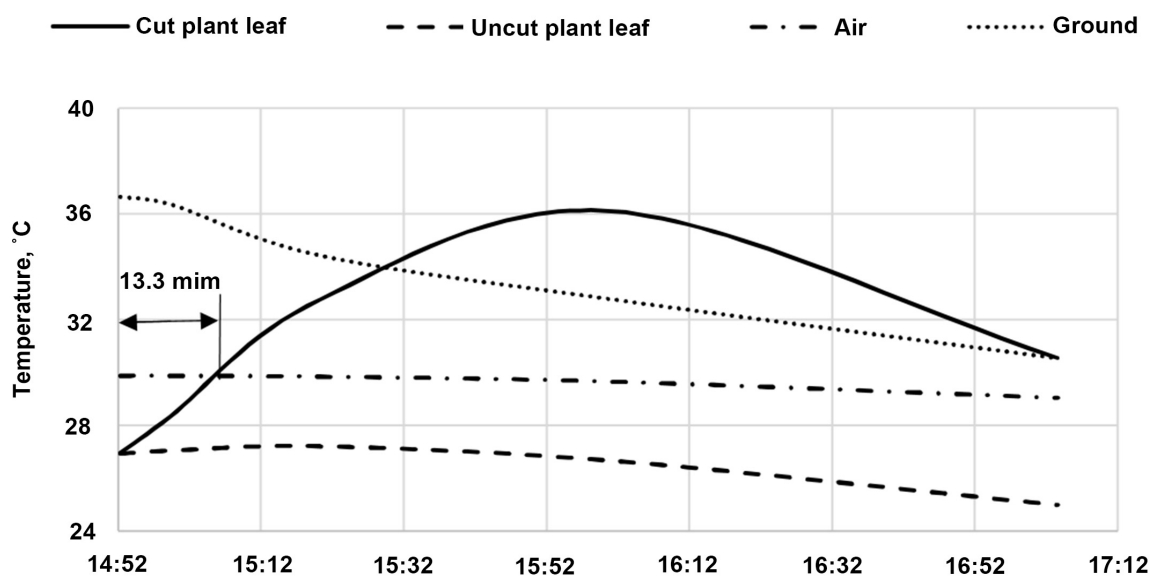

Figure 12. Leaf temperatures of cut and uncut main stem plants in relation to air and ground temperature at R6 growth stage, Lon Mann Cotton Research Station, Marianna, AR.

main stem during extreme drought situations, as illustrated in this experiment, will increase leaf temperatures is a function of solar radiation and air temperature.

Our measurements reveal that sap flow existed in the final growth stages of the soybean plants (R7 and R8) when leaves begin to senesce and plant tissue turns brown. Capillary potentials continue to transport water from moist soil to upper parts of the plant under the heat of incoming solar radiation. Mature, brown plant tissue absorbed water from the wet or irrigated soil intensively (Table 1). Up to $20 \%$ more moisture was absorbed from irrigated soil compared to non-irrigated soil. Pods and petioles attribute to increased moisture uptake. Main stems with pods removed also increased water uptake, probably because of micro-openings in stem-pod and stem-petiole connections.

Sap flow rates varied with growth stage (Table 2). Average sap flow of soybean plants at the R5 growth stage is high, $274 \mathrm{~g} /$ day per plant. Leaf area also reaches its maximum (LAI is 3 - 3.6) at R5 and accumulated ETp is $10.3 \mathrm{~cm}$, while accumulated sap flow is $13.4 \mathrm{~cm}$. The ratio of sap flow to accumulated ETp is 1.3 at R5, suggesting that a crop coefficient Kc (excluding soil the evaporation component) would be 1.3. At R6 growth stage, soybean water demand was half of R5 and averaged $0.36 \mathrm{~cm} /$ day. Daily sap flow was $0.46 \mathrm{~cm} /$ day at R6 to 0.18 $\mathrm{cm} /$ day at R6.9. The sap flow to ET ratio is changed from 1.2 at R6 to 0.4 at R6.9. The data reveal that soybean plants need supplemental irrigation water during R6 growth stage with intensity depending on soil moisture, stage of R6 growth, and weather conditions. Sap flow during R7 averaged $0.76 \mathrm{~cm} /$ day and around 10 times less water than high water use R5 growth stage.

\section{Conclusions}

Soybean plant water use and sap flow in high water demand and final growth stages varied with seed fill growth stage, soil water, and weather conditions. 
Table 1. Water absorption of dried soybean plants (grams) and its ratio to dry matter (\%), 2017, Lon Mann Cotton Research Station, Marianna AR.

\begin{tabular}{ccccc}
\hline & \multicolumn{2}{c}{ Non-irrigated soil } & \multicolumn{2}{c}{ Irrigated soil } \\
\cline { 2 - 5 } & $-\mathrm{g}-$ & $\%$ & $-\mathrm{g}-$ & $\%$ \\
\hline Whole plant, without seeds & 1.63 & 7.24 & 2.70 & 8.02 \\
Plant without pods & 0.21 & 2.22 & 0.68 & 4.54 \\
Stem & 0.57 & 6.65 & 0.73 & 8.26 \\
\hline
\end{tabular}

Table 2. Soybean direct measure sap flow and potential evapotranspiration estimated with Alfalfa referenced (\#54 canvas) Atmometer and average daily ratio of sap flow verusus ET during reproductive seed fill, 2017, Lon Mann Cotton Research Station, Marianna AR.

\begin{tabular}{cccccc}
\hline \multirow{2}{*}{$\begin{array}{c}\text { Growth } \\
\text { stage }\end{array}$} & \multicolumn{2}{c}{ Sap flow $(\mathrm{cm})$} & \multicolumn{2}{c}{ Evapotranspiration $(\mathrm{cm})$} & \multirow{2}{*}{ Sap:ET } \\
\cline { 2 - 4 } R5 & Daily & Sum & Daily & Sum & \\
\hline R6 & 0.74 & 13.39 & 0.58 & 10.31 & 1.3 \\
R6 - R6.5 & 0.36 & 10.06 & 0.43 & 11.76 & 0.9 \\
R6.5 - R6.9 & 0.46 & 4.65 & 0.41 & 6.34 & 1.2 \\
R6.9 - R7 & 0.38 & 4.17 & 0.41 & 4.42 & 0.9 \\
R7 & 0.18 & 1.24 & 0.48 & 3.33 & 0.4 \\
R8 & 0.08 & 1.23 & 0.36 & 5.49 & 0.2 \\
\hline
\end{tabular}

Derivation of soil moisture retention curves in-situ using soil-water tension profile and gravimetric moisture with bulk density measurements allowed for calculation of soil water. A strong correlation between sap flow and soil water content existed ( $\mathrm{R}^{2}$ around 0.9 ). Sap flow during seed fill was also correlated with ET and solar radiation. Maximum sap flow mainly occurs when ET is around 0.64 $\mathrm{cm}$, and ET demands greater than $0.76 \mathrm{~cm}$ may result in slightly decreasing sap flow. The ratio of biomass accumulation to sap flow indicated that portions of sap flow contributed to the biomass of the plant. Daily sap flow contribution to the plant biomass is approximately $0.5 \%-0.8 \%$ of sap flow rate in R5 growth stage, and $0.8 \%-1.2 \%$ in R6 growth stage. The higher allocation of sap flow to the plant biomass in R6 may be explained by physiological shifts toward seed fill gains from combined photosynthesis and remobilization sources.

To evaluate the process of water evaporation and sap flow, we recommend a solar radiation efficiency (SRE) value. The SRE represents the ratio among hourly solar energy received by the plant and amount of sap flow. SRE is relatively higher in the morning hours because of low water resistance. As water evaporation increases during the day, the water resistance increases and SRE is lower in afternoon hours. At the end of the day when solar radiation decreases, evapotranspiration decreases and the SRE slightly increases. The same effect occurred when the soil moisture decreased. The SRE values at $12 \%$ soil moisture at 
the top $0-15 \mathrm{~cm}$ soil layers were greater than when the soil moisture was $7 \%$ at relatively similar Leaf Area Index and incoming solar radiation.

Air and leaf surface temperature gradients of unstressed soybeans varied with plant growth stage. Air to leaf surface temperature gradients $(\Delta T)$ were higher during R5 growth stage, when maximum sap flow rates were observed, and decreased with sap flow in R6 growth stage. In R7 and R8 growth stages, $\Delta T$ values approached 0 and became less than 0 as leaves turned from yellow to brown prior to abscission. Additionally, $\Delta T$ correlated with the plant sap flow in a logarithmic function. Surface leaf temperatures immediately rose after cutting the plant main stem, and just after 13 min equilibrated to the air temperature.

Based on the ratio of sap flow and ET, our data suggest a crop coefficient (transpiration component of ET), Kc, of 1.3 during R5 growth, when the highest sap flow occurs. During R6 growth stage, the sap flow to ET ratio suggests crop Kc values decreasing from 1.2 at R6 to 0.4 at R6.9. The results indicate that soybeans may need supplemental irrigation water until R6.9 growth stage, depending on soil moisture and weather conditions. More research to examine the intricate relationships among roots and shoot soybean physiology, aerial environmental conditions, and soil moisture during seed fill of soybeans will aid in development of more efficient utilization of finite water and nutrient resources.

\section{Conflicts of Interest}

The authors declare no conflicts of interest regarding the publication of this paper.

\section{References}

[1] Payero, J.O. and Irmak, S. (2013) Daily Energy Fluxes, Evapotranspiration and Crop Coefficient of Soybean. Agricultural Water Management, 31-43.

[2] Moreshet, S., Huck, M.G., Hesketh, J.D. and Peters, D.B. (1990) Relationships between Sap Flow and Hydraulic Conductivity in Soybean Plants. Agronomie, 10, 381-389. https://doi.org/10.1051/agro:19900504

[3] Isoda, A. and Wang, P. (2002) Leaf Temperature and Transpiration of Field Grown Cotton and Soybean under Arid and Humid Conditions. Plant Production Science, 5, 224-228. https://doi.org/10.1626/pps.5.224

[4] Angadi, S.V., Culforth, H.W. and McConkey, B.G. (2003) Determination of the Water Use Response of Canola to Solar Radiation and Temperature by Using Heat Balance Stem Flow Gauges. Canadian Journal of Plant Science, 83, 31-38. https://doi.org/10.4141/P02-022

[5] Zhao, C.Y., Hua, J., Feng, Q., Teng, F.Y. and Pei, D.L. (2017) Comparative Study of Daytime and Nighttime Sap Flow of Populus euphratica. Plant Growth Regulation, 82, 353-362. https://doi.org/10.1007/s10725-017-0263-6

[6] Isoda, A. and Wang, P.W. (2002) Leaf Temperature and Transpiration of Field Grown Cotton and Soybean under Arid and Humid Conditions. Plant Production Science, 5, 224-228. https://doi.org/10.1626/pps.5.224

[7] Brown, R.D. and Gillespie, T.J. (1995) Microclimate Landscape Design: Creating Thermal Comfort and Energy Efficiency. John Wiley \& Sons, New York. 
[8] Mohd, F.S., Elias, S. and Mustafa, K.M.S. (2007) Effects of Tree Canopies on Solar Radiation Filtration in a Tropical Microclimatic Environment. PLEA 2007-The 24th Conference on Passive and Low Energy Architecture, Singapore, 22-24 November 2007.

[9] Rana, G. and Katerji, N. (2000) Measurement and Estimation of Actual Evapotranspiration in the Field under Mediterranean Climate: A Review. European Journal of Agronomy, 13, 125-153. https://doi.org/10.1016/S1161-0301(00)00070-8

[10] Ferrario, S., Agius, I. and Morisot, A. (1992) Daily Variation of Xylemic Exudation Rate in Tomato. Journal of Plant Nutrition, 15, 69-83.

https://doi.org/10.1080/01904169209364302

[11] Cohen Y., Huck, M.G., Hesketh, J.D. and Frederick, J.R. (1990) Sap Flow in the Stem of Water Stressed Soybean and Maize Plants. Irrigation Science, 11, 45-50. https://doi.org/10.1007/BF00189994

[12] Shao, G.C., Huang, D.D., Cheng, X., Cui, J.T. and Zhang, Z.H. (2016) Path Analysis of Sap Flow of Tomato under Rain Shelters in Response to Drought Stress. International Journal of Agricultural and Biological Engineering, 9, 54-62.

[13] Golden, M.L. and Field, C.B. (1994) Three Methods for Monitoring the Gas Exchange of Individual Tree Canopies: Ventilated Chamber, Sap-Flow and Penman-Monteith Measurements on Evergreen Oaks. Functional Ecology, 8, 125-135.

https://doi.org/10.2307/2390121

[14] Fehr, W.R. and Caviness, C.E. (1977) Stages of Soybean Development. Iowa State Univ. Coop. Ext. Ser. Spec. Rep, 80.

[15] Board, J.E. and Kahlon, C.S. (2012) Contribution of Remobilized Total Dry Matter to Soybean Yield. Journal of Crop Improvement, 26, 641-654. https://doi.org/10.1080/15427528.2012.666224

[16] Brown, R.D. and Gillespie, T.J. (1995) Microclimate Landscape Design: Creating Thermal Comfort and Energy Efficiency. John Wiley \& Sons: New York.

[17] Aasamaa, K. and Sõber, A. (2011) Responses of Stomatal Conductance to Simultaneous Changes in Two Environmental Factors. Tree Physiology, 31, 855-864.

https://doi.org/10.1093/treephys/tpr078 